\title{
DEVELOPING DIVERSE, EFFECTIVE, AND PERMANENT PLANT COMMUNITIES ON RECLAIMED SURFACE COAL MINES: RESTORING ECOSYSTEM FUNCTION ${ }^{1}$
}

\author{
Edward A. Vasquez ${ }^{2}$ and Roger L. Sheley
}

\begin{abstract}
Surface coal mine disturbances affect vegetation, soil chemical/physical properties, bedrock, and landforms. The scope of this article focuses on lands to be reclaimed back to rangelands (post-mine land use) similar to the pre-mine ecosystem in terms of plant composition/diversity, structure, and ecosystem function. Reclamation programs that solely emphasize plant community composition and structure rather than effectively repairing disturbed or altered ecological processes ignores the foundation upon which the sustainability of reconstructed plant communities depends. Reclamation success may be improved by addressing primary ecological processes driving ecosystem function as part of the reclamation process. Altered primary processes require repair of the physical system in conjunction with adding seeds or plants. Land-form design strategies, which are designed to capture, store, and release water effectively into reconstructed watersheds is the foundation of successfully reclaimed ecosystems. Because plant functional groups can differ in their spatial and temporal acquisition of resources, improving functional diversity may be a method to more fully utilize soil nutrients in reclaimed soils and improve resilience to weed invasion. Strategically combining species with different seed/seedling traits in seed mixtures can increase chances of achieving adequate plant establishment during revegetation. Monitoring program design should be an integral part of the reclamation planning process, and indicators reflecting landscape-scale processes can be adapted to monitor reclamation project success. Effective reclamation plans are process-oriented, seek to initiate self-repair, and address landscape interactions. The probability of achieving successful reclamation is enhanced by pursuing a broader goal of improving ecosystem vigor, organization and resilience utilizing novel assemblages of species that perform desired functions and produce a range of ecosystem goods and services. Reclaiming mined land requires realistic objectives that consider the ecological potential of the site, land-use goals, and socioeconomic constraints.
\end{abstract}

Additional Key words: Restoration, Revegetation, Biodiversity, Plant Functional Groups, Geomorphic Reclamation

1 Paper presented at the 2018 National Meeting of the American Society of Mining and Reclamation, St. Louis, MO The Gateway to Land Reclamation June 3 - 7, 2018. R. I. Barnhisel (Ed.) Published by ASMR, 1305 Weathervane, Champaign, IL 61821.

${ }^{2}$ Edward A. Vasquez, Ecologist, USDI - Office of Surface Mining Reclamation and Enforcement, 1999 Broadway, Denver, CO 80202; and Roger L. Sheley, Ecologist, USDA-Agricultural Research Service, 67826-A Highway 205, Burns, OR 97720

Journal American Society of Mining and Reclamation, 2018 Volume 7, Issue 1 pp 77-109 DOI: http://doi.org/10.21000/JASMR18010077 


\section{Introduction}

Historical or pre-mining land uses for surface coal mines in the western United States were largely rangelands used for livestock grazing, wildlife habitat, pasture, forest products, or cultural resources. Surface coal mine disturbances affect vegetation, soil chemical/physical properties, bedrock. and landforms (Liu et al., 2017). Mining activities including the removal of vegetation, topsoil, overburden, and coal affect attributes such as soil bulk density, $\mathrm{pH}$, electrical conductivity, soil organic carbon (SOC), and nutrient pools. This creates significant barriers making it problematic to reconstruct ecosystem function or the biological, geochemical, and physical processes and components that take place within an ecosystem (Shrestha and Lal, 2011). Often the first goal of reclamation is simply to stabilize the substrate or establish vegetative cover. To be effective, reclamation plans must be designed to re-construct not only a certain plant community structure, but also the corresponding function of an ecosystem (Bradshaw, 2004; Sanger and Jetschke, 2004).

The Surface Mining Control and Reclamation Act (SMCRA) of 1977 requires surface coal mine permittees to fully reclaim disturbed lands to the approximate original topography and productivity following mining activities. The scope of this article focuses on lands to be reclaimed back to rangelands similar to the pre-mine ecosystem in terms of plant composition/diversity, structure, and ecosystem function. In these cases, reclamation aims to recover biogeochemical functions and fundamental ecosystem services within the replacement ecosystem. In other words, an agreement has been made (approved) between stakeholders and the regulatory agency(s) that the reclaimed land and post-mine land use will be rangelands to be used for grazing, wildlife habitat, and/or cultural sites. As such, a successfully reclaimed site (reclamation) is defined in this article as supporting a post-mine land use similar to native sites in ecological functioning and contain similar plant functional groups. The various plant functional groups or guilds of species

established in reclaimed sites that share ecological characteristics (e.g., life-history traits and dispersal strategies) and play equivalent roles in reclaimed plant communities are important components of ecosystem function (Voigt and Perner, 2004; Alday et al., 2011).

In contrast, restoration is the process of re-establishing to the extent possible the structure, function, and composition of native ecosystems (Whisenant, 2005). The term revegetation is characterized as the process of planting raw mineral soils with perennial plants and less often annual plants, including rebuilding the soil, which encompasses moderate (reclamation) and 
complex (restoration) revegetation processes (NRCS, 2005). However, it should be noted that in order to provide the greatest ecosystem goods and services for all stakeholders, a post-mine land use may be approved by the regulatory agency(s) that is different from the pre-mine land use. This implies a repurposing of the landscape for its intended post-mine land use. For example, the approved post-mine land use may be industrial, and therefore, the goal of reclamation in this instance is not to reconstruct these sites similar to pre-mine native ecosystems.

Evaluation of reclamation is ultimately based on the specific requirements of the reclamation plan and the functional requirements of the post-mining land use (SMCRA, 1977). Indicators such as vegetative cover and composition may suggest successful reclamation. Process-based indicators such as water-flow patterns, rills, soil compaction, and plant community composition and distribution relative to water infiltration and runoff may suggest the opposite (Herrick et al., 2006a; 2006b). SMCRA success standards for revegetation are based on easily measurable indictors including ground cover, shrub density, plant diversity, and biomass production compared to either a reference area(s) or technical standards (e.g., $672 \mathrm{~kg} \mathrm{ha}^{-1}$ production). Consequently, many reclamation programs emphasize replacing plant community composition and structure, rather than effectively re-establishing or repairing damaged ecological processes and ecosystem function (Whisenant, 2005; Herrick et al., 2006b). One critical limitation of only using plant community indicators as the basis of reclamation success is this protocol ignores the ecological processes on which the sustainability of the reclaimed plant community depends upon. Ecological processes drive ecosystem function; therefore, strategies for surface mine reclamation should: 1) be process oriented; 2) attempt to initiate self-repair; and 3) consider landscape interactions (Mitsch and Jorgensen, 2003; Whisenant, 2005; Costanza, 2012).

Under SMCRA regulations, reclaimed plant communities must meet specified criteria that are indicative of diverse, effective, and permanent plant communities for their intended post-mine land use. SMCRA states reclaimed areas be comprised of species native to the area or comprised of introduced species where desirable and necessary to achieve the approved post-mine land use. Ecosystem health is closely linked to the notion of sustainability and implies the ability of the ecosystem to maintain its structure (organization) and function (vigor) over time in the face of external stress (resilience) (Herrick et al., 2006a; Costanza, 2012). Accordingly, reclamation approaches should be directed toward re-establishing the physical, chemical, and biological 
processes conducive to producing the goods and services reclaimed areas should provide (Herrick et al., 2006a).

The purpose of this article is to present ecological processes driving ecosystem function (vigor) and describe ecologically-based management considerations as part of the reclamation process and/or normal husbandry. The specific objectives of this article are to 1) describe primary ecosystem processes driving hydrologic function, soil/site stability, and biotic integrity; 2) illustrate constraints of plants growing in adverse soil conditions; 3) discuss assisted plant community succession and reconstructing ecosystem function; and 4) examine management implications. The impetus is these goals (i.e., re-constructing ecosystem function and sustainability) can be achievable within the current framework of SMCRA and the operators' currently approved reclamation plan.

\section{Processes Driving Hydrologic Function, Soil and Site Stability, and Biological Integrity}

$\underline{\text { Hydrologic Function }}$

Land disturbed by mining activities is typically backfilled and graded to the approximate original contour (AOC). Because little vegetative cover or biomass during the initial phases of reconstruction is present on site, resource flows from landscapes are controlled by the newly reconstructed landform and micro-topographic features (Whisenant, 2005). Geomorphic processes and landforms function at larger scales to control resource flows by the fluvial (water) or eolian (wind) transport of soil, water, nutrients, basic cations, and organic materials (Whisenant, 2005; Mossa and James, 2013). The relative position on the landform affects runoff rates, watercapture and erosion potential. Reclamation strategies designed to capture, store, and release water effectively into re-constructed watersheds is the foundation of successfully reclaimed ecosystems. Erosion on mined landforms attempts to re-establish the dynamic equilibrium between landforms and processes. The quality of overburden is important, but the objective is to reduce slippage and promote root penetration.

Consequently, geomorphic reclamation approaches should create a stable landform by reproducing the natural landform's evolution to the mature stage, resulting in stable slopes and channels, in balance with local environmental conditions. Successful geomorphic designs reestablish suitable hydrologic function for balance transport of water and sediment from the reclaimed land surface (Martin-Duque et al., 2010; Mossa and James, 2013). Consideration of 
geomorphic stability and channel design while considering the landscape within the mine permit boundary and expanded landscape impact area is critical (DePriest et al., 2015). Hence, connectivity or the capacity of a landscape to support the movement of organisms, materials, or energy generally includes linkages of biotic and physical processes (Love and Bates, 2009).

Figure 1a-b illustrates a mature landform and a mature drainage channel following geomorphic reclamation. Geomorphic reclamation aims to increase diversification of landforms, enhance sustainability, and define ridges and valleys while honoring the major drainage routes. Use of geomorphic principles in surface coal mine reclamation to design mature landforms also serves to improve the aesthetic appearance and provide a wider range of habitats for wildlife than traditional reclamation strategies (e.g., terraces). However, constructing landforms that naturally blend into the steep slopes of the surrounding environment may not ensure stability (DePriest et al., 2015). Long straight slopes can often foster large surface-flow rates and should be avoided if feasible (Fig. 2). In arid and semi-arid regions, creating terrain diversity on reconstructed landforms increases the potential to capture and store water, providing a solution to a key limiting factor and spatial variation (Bugosh, 2004; Martin-Duque et al., 2010).
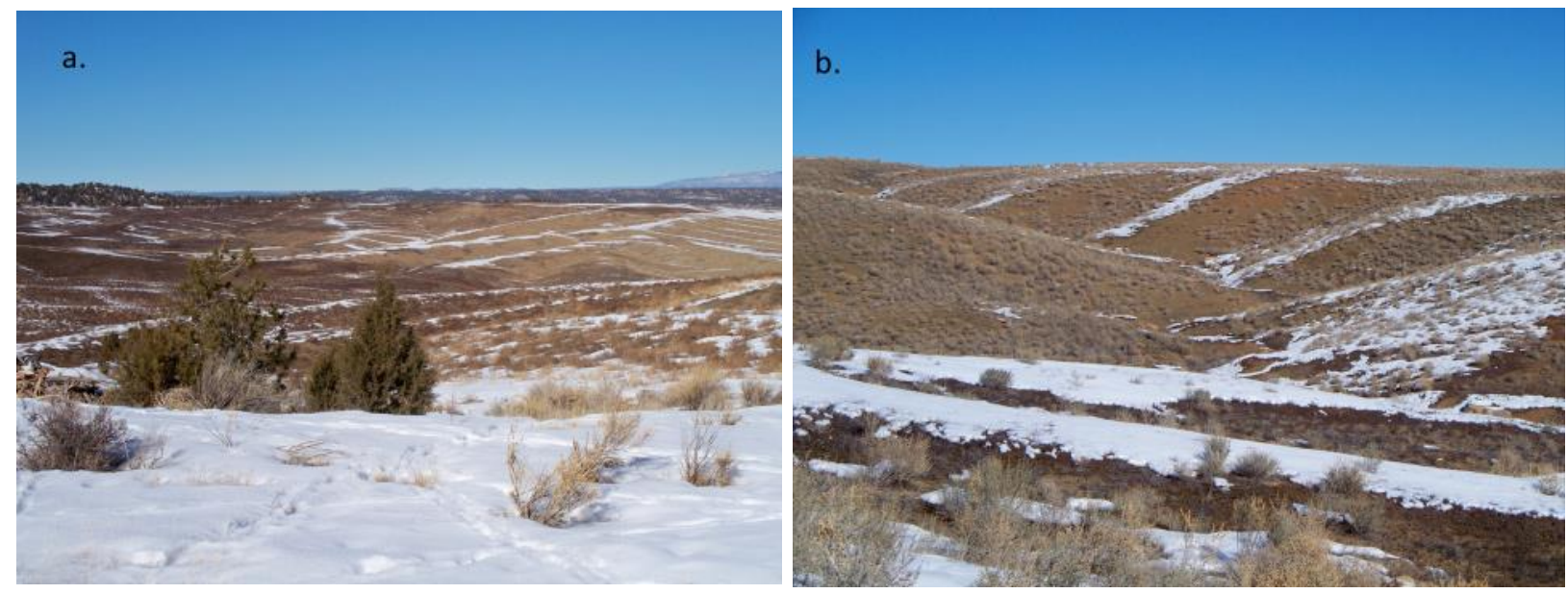

Figure 1a-b. Mature stages of reclamation showing a.) Geomorphically reclaimed landform; and b.) Geomorphic reclamation on drainage channel. Photos by Mychal Yellowman (2010). 


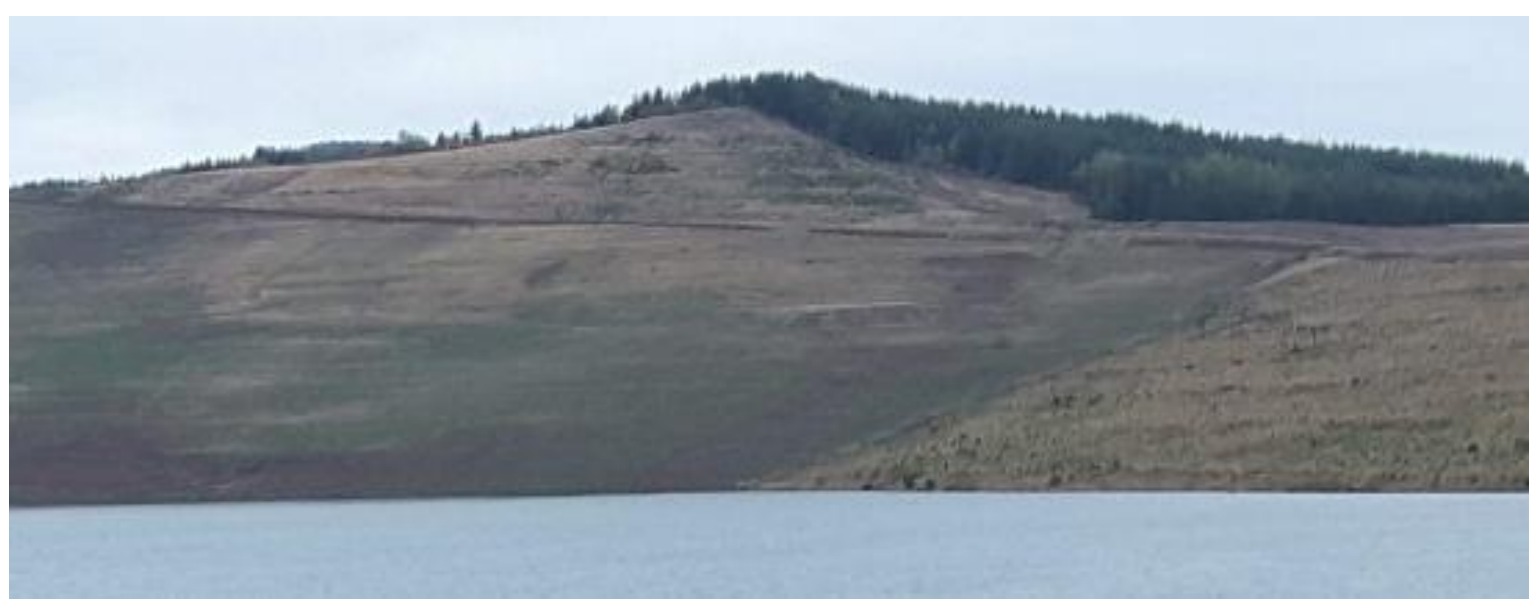

Figure 2. Photo showing long, straight slopes driving large surface-flow rates. Photo by Ed Vasquez (2017).

Water Infiltration, Penetration and Runoff. Water infiltration is the process of water entry into the soil, which is typically by downward flow through all or part of the soil surface (Hillel, 1998). The ability of water to infiltrate the soil largely depends on 1) time from the onset of rain;2) initial soil water content; 3) soil hydraulic conductivity; 4) surface conditions; and 5) profile depth and layering (Hillel, 1998; Ryel et al., 2003; Reynolds and Reddy, 2012). Lower water infiltration creates more water runoff, less soil penetration, reduced moisture available to plants, and greater potential for sediment erosion (Herrick et al., 2006a). The rate of infiltration relative to the rate of water supply will determine how much water enters the root zone versus how much water will runoff. The relationship between the return of soil moisture, the return of vegetative cover, and recovery of soil properties is enhanced by adequate infiltration capacity of reclaimed soils (Reynolds and Reddy, 2012).

Insufficient water penetration is a result of the inability of enough water to infiltrate deep enough into the active root zone to sustain the plant until the next precipitation event (Ryel et al., 2003). Soil porosity determines the rate water moves in the soil, the amount of water stored, and ultimately water made available to plants (Whisenant, 2005). A principal obstacle of seedling establishment after topsoil replacement is soil compacted by machines. Soil compaction reduces soil pore space, increases bulk density $\left(\mathrm{g} \mathrm{cm}^{-3}\right)$, lowers water infiltration, and lowers drainage capacity. Reduced microsites in soils are affected by compaction, and water-filled pores greatly restrict the movement of oxygen into these regions of compaction. Because plants have high rates of respiration, roots have a high demand for oxygen and the transfer of gases between soil and atmosphere occurs mainly in air-filled soil pores (Brady and Weil, 2002). When extensive soil 
compaction occurs, the amount of pore space is lowered whereby a decrease in total porosity lowers the rate at which the respiration process occurs. This leads to the roots asphyxiating and the decrease in pore space reduces water infiltration and penetration into the soil.

In arid and semi-arid lands in the southwestern U. S., Byrne et al. (2017) found topsoil saturated hydraulic conductivity decreased with increasing bulk density. Results from this investigation suggest that matric potentials during the study period were often too low (i.e., drought conditions) for enough plant growth for vegetation establishment. Equipment such as scrapers provide selective soil depth removal, storage, and replacement; however, they greatly compact soil, and require multiple trips over the same surface during the removal and replacement process. Tillage treatments applied prior to topsoil re-spreading may not be effective in reducing bulk density because the subsoil materials will be re-compacted following topsoil re-spreading with scrapers (Schroeder and Vining, 1993). In contrast, tracked equipment induce little compaction and retain pore space. Overall compaction can be reduced by controlling traffic lanes within an active reclamation area and heavy equipment should not be allowed on wet soils for replacement or removal as there is more opportunity for compaction.

Infiltration can be improved by preventing soil crusts, disking, soil organic matter management, or chemical amendments (Franzluebbers, 2002). Redistribution of rainwater by roots was observed by Ryel et al. (2003) in semi-arid plant communities of different structural and functional forms indicating this is likely a wide-spread phenomenon. Rapid redistribution of soil moisture by roots can potentially alter the dynamics of water penetration deeper in the soil profile (Ryel et al., 2003).

\section{$\underline{\text { Soil/Site Stability }}$}

Soil erosion removes the most fertile part of the soil and lowers productivity of the site. Erosion control during the reclamation process involves a combination of soil stabilization plus runoff control. Reclaimed soils used for growth medium are typically a combination of topsoil and/or unconsolidated suitable material removed from the site pre-mining. Top soil suitability is based on either State and/or Federal requirements, baseline soil properties, or post-mining land use. An immediate objective following topsoil or suitable-material replacement is initiating the vegetative, chemical, or mechanical measures used to shield the soil from impact of raindrops or to bind the soil in place. Runoff control consists of the structural measures designed to prevent offsite water 
from entering the site, reduce the amount of runoff and its velocity on the site. On a macro scale the primary goal is to prevent sediment from leaving the site by reducing the ability of runoff to transport sediment and containing the sediment on the site. Disturbed mine water runoff handling systems include diversion ditches, culverts, sumps, and sediment ponds. Sediment ponds can be constructed per Federal and State regulations to impound surface runoff for the purpose of settlement of suspended solids, and treatment if required, prior to discharge to the drainage channels. The objective is to dissipate the runoff velocity which causes sediment to drop out of suspension. Surface roughness helps to reduce the velocity of wind across the soil surface (i.e., contour furrowing/spillage, undulations, tracking, and rocks) and also increases the available surface area for water to infiltrate into the soil (Whisenant, 2005). Specific seed mixtures for revegetation can be designed for temporary stabilization, rill and gully repair, permanent pondsites, and permanent drainage channels.

Basic principles of erosion control are to minimize land disturbances, intercept and divert runoff, and reduce runoff velocity. The initial focus is to prevent offsite sedimentation and provide permanent stabilization as soon as possible after final grading. Temporary stabilization methods can be utilized for seasonal or unforeseen delays; nonetheless, top-soiled areas require maintenance before, during, and after disturbance. Ground cover is the most important predictor of erosion resistance (Herrick et al., 2006b). The spatial distribution of perennial vegetation and proportion of the soil surface exposed in large $(>50-\mathrm{cm})$ inter-canopy and basal gaps may indicate incomplete recovery of revegetation. Thus, indicators such as water flow patterns, rills, and soil compaction help to identify the processes (e.g., infiltration and runoff) limiting reclamation success (Herrick et al., 2006a; 2006b).

\section{$\underline{\text { Biotic Integrity }}$}

Soil Organic Matter. Pools of soil organic matter (SOM - humus) include litter, plant residues, microbial biomass, faunal biomass, water-soluble organics, belowground plant constituents, and stable humus (Stevenson and Cole, 1999). The percentage of SOM present in reclaimed soils has a substantial influence on plant production and soil properties and provides a favorable habitat for micro- and macro faunal organisms. Soil organic matter provides carbon and energy sources for microorganisms (Stevenson and Cole, 1999; Sparks, 2003). Soil organic matter is made up of organic residues (e.g., un-decayed plant material), humus (i.e., biomolecules and humic substances), and soil biomass (e.g., live microbial tissue). Formation of humus in soil or SOM 
decay is driven by microbial oxidation of organic carbon compounds. Humic substances have no singular molecular structure, but contain functional groups (e.g., $-\mathrm{COOH}$ and $-\mathrm{OH}$ ) which complex with metals (Brady and Weil, 2002; Sparks, 2003). The decay of organic residues in soil is accompanied by the conversion of $\mathrm{C}$ and $\mathrm{N}$ into microbial cells and other products. Residues with $\mathrm{C} / \mathrm{N}$ ratios $>30$ lower mineral $\mathrm{N}$ reserves because of net immobilization. In contrast, residues with $\mathrm{C} / \mathrm{N}$ ratios below about 20 typically lead to an increase in mineral $\mathrm{N}$ levels through net mineralization (Stevenson and Cole, 1999; Brady and Weil, 2002).

Organic carbon and microbial biomass appear to be stabilized in soils through the interaction with clay minerals. Interactions of SOM with soil clays have major implications for soil particle surface reactivity and stabilization of organic $\mathrm{C}$ against degradation and coat the clay surfaces thereby influencing their chemistry (Rakhsh et al., 2017). Exchangeable cations exert their influence on microbial biomass and carbon dynamics by controlling the size and activity of the microbial populations through modifying the physicochemical characteristics of microbial habitats (Rakhsh et al., 2017). The use of perennial plants and inclusion of SOM helps to improve reclaimed soils. In cases of reclaimed soils with poor physical structure or water-holding capacity, organic additions can have favorable effects including maintenance of SOM and enhance biological life (Stevenson and Cole, 1999). Thus, SOM greatly influences the soil biology, chemical, and physical properties of the soil and is very important in improving soil fertility in reconstructed ecosystems (Havlin et al., 2005; Herrick et al., 2006b; Thavamani et al., 2017). Establishing a monitoring system, reducing soil erosion, minimizing disturbances, and increasing the quantity and quality of soil organic matter are priorities for properly managing soil humus (Herrick et al., 2006b; Thavamani et al., 2017).

Nutrient Availability. There can be a large discrepancy between the concentrations of mineral nutrients in reclaimed soils and nutrient requirements of plants (Marschner, 2012; Liu et al., 2017). Many native plant communities evolved under low fertility and are poorly equipped to compete under enriched conditions and because of genotype, there are distinct differences between plant species capability to acquire resources (Davies et al., 2007, Vasquez et al., 2008; Marschner, 2012). Some plants preferentially uptake certain mineral elements (e.g., $\mathrm{K}^{+}$) while other plants accumulate concentrations of certain elements in their cell sap compared to the external solution (Vasquez et al., 2006). Differences of rhizo-deposition (i.e., root exudates - carbon compounds) by various plants species into the surrounding soil leads to a proliferation of microorganisms 
within and surrounding the root system, thereby influencing the rhizosphere and nutrient uptake by roots (Jones et al., 2004). The uptake of nutrients by roots leads to the release of $\mathrm{H}^{+}$into the soil to compensate for excess cation uptake and is pronounced during the uptake of $\mathrm{N}$ in the form of $\mathrm{NH}_{4}{ }^{+}$. If the soil is acidic and $\mathrm{N}$ is taken up in the form of $\mathrm{NO}_{3}{ }^{-}$, the release of $\mathrm{OH}^{-}$or $\mathrm{HCO}_{3}{ }^{-}$ can occur leading to an increase in rhizosphere $\mathrm{pH}$ (Jones et al., 2004). Most $\mathrm{N}$ in the surface soil is in organic forms, and therefore, the organic $\mathrm{C}$ content and total $\mathrm{N}$ content of the soil are closely related. Because functional groups can differ in their spatial and temporal acquisition of resources, improving functional diversity may be a method to more fully utilize soil nutrients (Davies et al., 2007).

Nutrient recycling in natural soils is powered by the carbon cycle and driven by soil organisms. The process is regulated by food web pathways that decompose matter into mineral nutrients. A soil system cycles nutrient through plant uptake, assimilation, deposition, decay, and release back to the soil. Movement of low-molecular-weight solutes (e.g., ions, organic acids, amino acids, sugars) from the external solution through the walls of individual root cells is a non-metabolic process driven by diffusion or mass flow (Marschner, 2012). The $\mathrm{pH}$ of the external soil solution can have extreme effects on the uptake of nutrients by plant roots, which include: 1) effects of solution $\mathrm{pH}$ on the chemical species present in solution; and 2) effects on concentrations of ions present in the apoplast of root cells. This is important to the uptake of solutes that can be protonated and are transported across the plasma membrane as specific chemical species (e.g., B, $\mathrm{PO}_{4}^{-3}$, and $\mathrm{NH}_{4}{ }^{+}$). In alkaline soils, the availability of $\mathrm{P}, \mathrm{Zn}, \mathrm{Fe}, \mathrm{Mn}, \mathrm{Cu}$, and $\mathrm{B}$ is very low. In contrast, plant growth is mainly limited to toxic concentrations of $\mathrm{Al}^{3+}$ and $\mathrm{Mn}^{2+}$ in acid soils (Marschner, 2012).

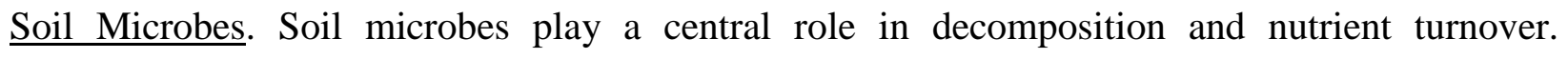
Microorganisms are involved in oxidation, nitrification, ammonification, nitrogen fixation, and other nutrient cycling processes (Vasquez et al., 2008). Soil microbes store carbon and nutrients in their biomass which are mineralized after cell death by surviving microbes making nutrients available to plants (Yan et al., 2015). Growth and activity of microorganisms (where present) is mainly limited by carbon availability and changes in microbial density along the root axis of plants influences nutrient turnover within the microbial biomass (Marschner, 2012). An increase in microbial biomass may result in net immobilization of nutrients, whereas a decrease in microbial biomass can cause a net release of nutrients (mineralization). 
Mycorrhiza is the most widespread association between microorganisms and higher plants resulting in the increase in below-ground surface area (roots and mycorrhizal hyphae) for acquisition of nutrients. Results from a study by Li-ping et al., (2009) suggest that the inoculation of arbuscular mycorrhiza increased the nutrition absorption of plants and organic content in the substrate, improving fertility of the surface coal mine reclamation area. The most distinct effect of arbuscular mycorrhiza on plant growth is the improved supply of nutrients of low mobility in the soil solution, particularly phosphorous. Non-mycorrhizal plants (e.g., Chenopodiaceae species) do occur in habitats where the soils are either very dry, saline, water logged, severely disturbed (e.g., mining activities), or where soil fertility is extremely high or extremely low. However, soil microbial communities can be important for successful reclamation in many ecosystems as post-mined soils typically have low microbial diversity, biomass, and enzymatic activity (Waterhouse et al., 2014; Dorr de Quadros et al., 2016; Thavamani et al., 2017). Consequently, mining processes that cause changes in soil $\mathrm{pH}$, increased compaction, loss of soil organic carbon, and increased erosion directly affect the soil microbial community and may trigger severe impact on the biogeochemical cycles (Dorr de Quadros et al., 2016; Spargo and Doley, 2016).

Topsoil stockpiling induces anaerobic conditions at and below a depth of 1-m where macrosoil organisms (e.g., earthworms) do not survive (Boyer et al., 2011). A study by Mushia et al. (2016) conducted at a surface coal mine in South Africa suggests the depth of the stockpile affects the quality of the topsoil at replacement and topsoil stored at depths greater than 1-meter can have a negative effect on plant growth. Mixing topsoil stockpiles greater than 1-m depth prior to replacement helped to improve the productivity of their study area. Therefore, intuitively, topsoil should not be stockpiled greater than 1-m deep where feasible. However, the footprint of shallowdepth stockpiles can be much greater and may be a constraint to mine operations. Direct haul of topsoil should be prioritized whenever it is logistically and economically feasible. When direct haul is not applicable, low stockpiles should be utilized as they will be comprised of a higher proportion of good quality soil (at the surface) and a lower proportion of anaerobic and compacted soil (Boyer et al., 2011). In order to reduce compaction and potentially anaerobic conditions, soil removal and replacement should be completed when dry ( $<75 \%$ soil moisture if possible). 


\section{Constraints of Plants Growing in Adverse Soil Conditions}

Because of disturbances related to equipment used for topsoil salvaging and storage prior to reclamation activities, large differences exist between pre-mine versus post-mine soil conditions. Constraints of plants growing in adverse soil conditions include low nutrient availability, acidity, poor aeration, alkalinity and salinity (Liu et al., 2017). Mine reconstructed soil physiochemical characteristics can vary notably more across distances of 1-m to 100-m compared to most natural soils. Conversely, soil characteristics have been found to vary less across distances of 100-m to 1000-m compared to most natural soils (Dollhopf, 2000). Disturbance to ecosystems from surface mining is significant and involves the same processes driving primary succession during the reconstruction of the ecosystem. Therefore, reclamation should involve these same processes (Bradshaw, 2000; Bradshaw, 2004).

Following the completion of grading within logical reclamation units and often prior to redistribution of soil and supplemental material, the graded spoil in all mining areas must be systematically sampled to identify the extent, nature, and location of unsuitable materials. The primary objectives in evaluating soil characteristics for reclamation purposes are to understand the nature of mine spoil properties compared with natural soil, and to identify limiting conditions to plant physiological tolerances requiring remediation (Brown et al, 2003). The parameters and criteria used to evaluate spoil suitability are based upon the characteristics of the overburden and spoil that are likely to be deleterious to plant growth. For example, parameters for evaluating

recently graded spoil typically include: $\mathrm{pH}$, electrical conductivity - EC (mmhos $\left.\mathrm{cm}^{-1}\right)$, sodium absorption ratio (SAR), texture (i.e., \% clay or sand), percent rock fragments and calcium carbonate equivalent, acid-based potential, and selenium (ppm). Sampling should continue until the confidence level is high and the real extent of unsuitable material in the reclamation unit is determined. Graded spoils that are determined to be unsuitable are typically covered with soil sometimes in combination with suitable overburden and supplemental surface plant growth media to ensure a viable root-zone.

\section{Cation exchange capacity (CEC)}

Both the clay and organic matter particles have a negative charge which attract and hold a complex group of cations. Cation exchange capacity is defined as the sum total of exchangeable cations (e.g., $\mathrm{Al}^{+}, \mathrm{NH}_{4}^{+}, \mathrm{K}^{+}, \mathrm{Na}^{+}, \mathrm{Mg}^{2+}, \mathrm{Ca}^{2+}$ ) that a soil particle surface can adsorb and is 
expressed in centimoles charge per kilogram $\left(\mathrm{cmol}_{\mathrm{c}} \mathrm{kg}^{-1}\right)$ of soil where $c$ is the charge (Brady and Weil, 2002). The CEC is important since it determines the capacity of a soil to retain ions in a form such that they are available for plant uptake and not susceptible to leaching in the soil profile (Sparks, 2003). Because sandy soils are generally low in all colloidal material, these soils have low CEC's compared to those exhibited by silt loams and clay loams.

In contrast, humic substances are large molecular weight molecules (2000 to 300,000 $\mathrm{g} \mathrm{mole}^{-1}$ ) and typically accounts for 50 - 90 percent of the cation-adsorbing power of mineral surface soils (Stevenson and Cole, 1999; Sparks, 2003; Brady and Weil, 2002). The extent of negative charge on humus colloids resulting from their associated functional groups is $\mathrm{pH}$ dependent and at high $\mathrm{pH}$ values, the CEC of humus on a mass basis (150 to $300 \mathrm{cmol}_{\mathrm{c}} \mathrm{kg}^{-1}$ ) far exceeds that of most silicate clays (Brady and Weil, 2002).

\section{Acid Sulfate Soils and Acid Generation}

Substratum materials underlying the topsoil typically have limiting layers of toxic materials (i.e., Fe, Mn, Al, various salts, etc.) that may have an extreme effect on successful vegetative growth. High $\mathrm{Mn}^{2+}$ and $\mathrm{Al}^{+}$soil concentrations can inhibit root growth, reducing water and nutrient uptake and consequently inhibiting plant productivity. Active acidity represents the $\mathrm{H}^{+}$ and $\mathrm{Al}^{+3}$ concentration in the soil solution. In contrast, potential acidity represents the $\mathrm{H}^{+}$and $\mathrm{Al}^{+3}$ on the CEC (Havlin et al., 2005). The maximum threshold limits for evaluating recently graded spoil such as $\mathrm{pH}$ and acid-base potential (ABP) are stated in the mine operators currently approved Permit Application Package (PAP) or reclamation plan. Typically, the maximum threshold limit for recently graded spoil is $\mathrm{pH}<4.5$ and $\mathrm{ABP}<-1.5$ (1 to 3-feet depth).

Measurements of $\mathrm{pH}$ only measures active soil acidity and does not indicate the amount of amendments needed to correct for acidity. Buffer $\mathrm{pH}$ measures the exchangeable or potential acidity and defines the resistance of the soil to a change in $\mathrm{pH}$. Potential acidity takes in to consideration the type of material textural and composition of the material and how much liming or quantity of $\mathrm{CaCO}_{3}$ is needed to increase the soil $\mathrm{pH}$ to a desired level (Havlin et al., 2005). Liming acidic mineral soils enhances root extension and also root hair length resulting from the increase in $\mathrm{pH}$ and $\mathrm{Ca}^{+2}$ supply. The lime requirement of a soil is related not only to soil $\mathrm{pH}$, but also to its buffering capacity or CEC (Sparks, 2003; Havlin et al., 2005). Soils with high clay and/or high OM have higher buffering capacities and lime requirements, whereas coarse-textured soils low in clay and OM have lower buffering capacities and lime requirements 
(Havlin et al., 2005). Each type of lime available has advantages and disadvantages. For example, typical agriculture lime is cheap, long-lasting, and handles easily; however, it is slow-acting. In contrast, liquid lime is convenient and fast-acting; although, it is expensive and does not last long.

Sulfur in coal and rocks associated with coal mines can occur as organic sulfur, sulfate sulfur, and pyritic sulfur. Pyritic or sulfide sulfur is the dominant form of sulfur in the majority of coal and associated rocks and is the sulfur form of greatest concern (Skousen et al., 1998). The total sulfur content of the rock accurately quantifies the acid-producing potential, if it were all to react. In general, sulfide rich and carbonate poor materials are expected to produce acidic drainage. Mitigating these types of soil conditions typically involves burying these sites or patches with approximately $0.3-\mathrm{m}$ to $1.2-\mathrm{m}$ of suitable topsoil material. Correction for sulfates and organic sulfur naturally present in some overburdens or resulting from partial weathering of pyritic materials may be necessary to increase accuracy in predicting the acid-producing potential of materials containing mixed sulfur species. When common sulfide (e.g., pyrite) and sulfate (e.g., gypsum) minerals are subjected to acid-base account ( $\mathrm{ABA}$ ) analytical extraction methods, the ABA method may fail to distinguish accurately the acid forming from non-acid forming minerals and may result in errors in the determination of potential acidity (Jennings and Dollhopf, 1995).

Gypsum $\left(\mathrm{CaSO}_{4} \cdot \mathrm{H}_{2} \mathrm{O}\right)$ applied to acidic soils does not alter the $\mathrm{pH}$ but enhances root growth by providing $\mathrm{Ca}$ and decreasing $\mathrm{Al}$-toxicity (e.g., formation of non-toxic $\mathrm{AlSO}_{4}{ }^{+}$ions) (Marschner, 2012). In addition to poor aeration and high mechanical impedance, low subsoil $\mathrm{pH}$ is an important factor in restricting subsoil penetration by roots (Marschner, 2012). Increased penetration of roots into acidic subsoils can be achieved by: 1) amelioration of subsoil acidity (e.g., leaching of dissolved lime application into subsoil layers); 2) applying gypsum that increases concentration of $\mathrm{Ca}^{+2}$ in sub-soil (leaching of gypsum is greater than that of lime because of its greater solubility); 3) using Al-tolerant plant species or genotypes (e.g., wheat); or 4) the combination of liming and Al-resistant genotypes.

\section{Calcareous and Alkaline Soils}

These soils are very common in arid and semi-arid climates receiving < 20-inches percipitation year $^{-1}$ and can be grouped into either calcareous or alkaline (sodic or saline) soils (Havlin et al., 2005). The $\mathrm{pH}$ of calcareous soils is determined by the presence of $\mathrm{CaCO}_{3}$, which buffers the soil. Calcareous soils are typically deficient in Fe, Zn, P, and to a lesser extent Mn. Other constraints 
of calcareous soils include excess $\mathrm{HCO}_{3}{ }^{-}$, water deficit, and mechanical impedance (i.e., hardpan). In contrast, alkaline soils have a $\mathrm{pH}>8.5$. Major nutritional constraints of alkaline soils include $\mathrm{Na}$ and $\mathrm{B}$ toxicity and deficiency of $\mathrm{Zn}, \mathrm{Fe}, \mathrm{P}$, and to a lesser extent $\mathrm{Ca}, \mathrm{K}$, and $\mathrm{Mg}$. Additional constraints of alkaline soils include poor aeration, excess $\mathrm{HCO}_{3}{ }^{-}$, water deficit, and mechanical impedance (Marschner, 2012).

When salts are present in the parent material or the groundwater, arid conditions lead to capillary rise of water from depths, which will bring this salt into the topsoil. Saline soils are not necessarily alkaline, and plant growth on saline soils is affected mainly by high concentrations of $\mathrm{NaCl}$ (i.e., ion toxicity or ion imbalance) and impairment of water balance. Salinity also affects plant growth regulators and suppresses seed germination and root and shoot growth (Radhakrishnan and Baek, 2017). Several interrelated parameters are commonly used to quantify salt affected soils. The electrical conductivity $\left(\mathrm{EC}_{\mathrm{se}}\right)$ of the saturated extract can be measured whereby a high $\mathrm{EC}_{\mathrm{se}}$ means higher salt concentrations or more ions in solution (Havlin et al., 2005). A second parameter is the sodium adsorption ratio (SAR) which deals with comparative concentrations of $\mathrm{Na}^{+}, \mathrm{Ca}^{2+}$, and $\mathrm{Mg}^{2+}$ in the soil solution and is related to the quantity of $\mathrm{Na}^{+}$on the CEC. Exchangeable sodium percentage (ESP) is a third parameter that may be used to identify saline and/or sodic soil conditions and is the ratio of exchangeable $\mathrm{Na}^{+}$to the CEC of the soil. Lastly, soil pH can be used to determine whether soils are saline or sodic (Yan et al., 2015).

Saline soils have an $\mathrm{EC}_{\mathrm{se}}>4 \mathrm{mmhos} \mathrm{cm}^{-1}$, sodium adsorption ratio $(\mathrm{SAR})<13$, and $\mathrm{pH}<8.5$, with an ESP < 15 (Sparks, 2003; Havlin et al., 2005; Yan et al., 2015). Salts found in saline soils are mainly chlorides and sulfates of $\mathrm{Na}^{+}, \mathrm{Ca}^{2+}$, and $\mathrm{K}^{+}$; although, poor soil physical condition is commonly not a problem on saline soils. Conversely, sodic soils are alkaline and plant growth is impaired mainly by high $\mathrm{pH}$, high bicarbonate and often poor aeration. Sodic soils occur when $\mathrm{EC}_{\mathrm{se}}<4$ mmhos $\mathrm{cm}^{-1}$, ESP > 15, SAR > 13, and pH > 8.5 (Sparks, 2003; Yan et al., 2015). In sodic soils, excess $\mathrm{Na}^{+}$disperses soil colloids and creates nutritional disorders in most plants. Sodic soils are the most troublesome of the basic conditions described above. Sodic soil chemical and physical conditions discourage growth of plants. The effective electronegativity of soil colloid particles causes them to disperse breaking up soil aggregates, dispersed soil colloids clog soil pores, water infiltration is reduced and soil crusting is increased leading to puddled soils conditions. Physical and chemical conditions of saline-sodic conditions are relatively similar to saline soils as a result of moderating influence of neutral salts. Saline-sodic soils have both 


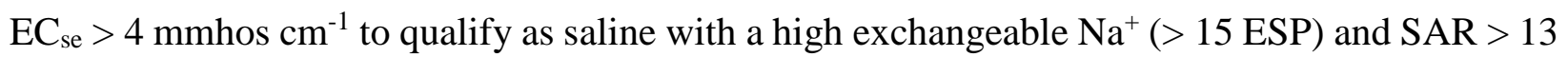
to qualify as sodic; however, soil $\mathrm{pH}$ is usually $<8.5$. In contrast to saline soils, when the salts start to leach out, the exchangeable $\mathrm{Na}^{+}$hydrolyzes and the $\mathrm{pH}$ increases, which results in sodic soils (Sparks, 2003; Havlin et al., 2005; Yan et al., 2015).

Thus, soil salinity reduces plant growth and microbial functioning. As with acid soils, mitigation of saline soils is typically by burying these with an appropriate amount of suitable topsoil material. There is no soil amendment that can be used to improve the growing conditions of saline soils. Therefore, practices that improve drainage (e.g., deep disking to break up hardpan or claypan) and reduce evaporation (i.e., mulch application) helps to reduce salt concentrations within the rhizosphere and soil surface. The impetus is to improve the downward flow and penetration of water into the soil profile and minimize evaporation (Sparks, 2003; Havlin et al., 2005). The use of a salt balance approach is needed to avoid saline conditions in the soil profile where the post mine land use is cropland. Where irrigation is an option in soils with good structure, reclamation of saline soils involves leaching (flushing soil profile) of salts below the root zone with good quality water (i.e., low salinity) with effective internal drainage. The approximate leaching requirement equals the ratio of salinity of irrigation water $\left(\mathrm{EC}_{\mathrm{water}}\right)$ to maximum possible salinity of the soil solution for a particular group of species to be grown. Thus, the leaching requirement would be the water added in excess of that needed by the plants. For sodic soils, $\mathrm{Ca}^{2+}$ is commonly used to replace $\mathrm{Na}^{+}$on the exchange complex. Gypsum amendment $\left(\mathrm{CaSO}_{4} \cdot 2 \mathrm{H}_{2} \mathrm{O}\right)$ is a good source of $\mathrm{Ca}^{2+}$ and can be used to correct saline-sodic and sodic soils. A sufficient amount of gypsum should be applied to effectively exchange $\mathrm{Ca}^{2+}$ for $\mathrm{Na}^{+}$on exchange sites and leach $\mathrm{Na}_{2} \mathrm{SO}_{4}$ with ample quantities of irrigation water. Elemental sulfur can be used in the amendment process to address sodic soils (Havlin et al., 2005). Both sodic and saline soils require leaching below the root zone.

Plant materials (seed or nursery seedlings) should be developed from local collections if possible or obtained from regional sources with similar habitat characteristics, or commercial sources using local genotypes that are site adapted to calcareous and saline soils. Species from the Chenopodiaceae family such as fourwing saltbrush (Atriplex canescense), shadscale (Atriplex confertifolia), greasewood (Sarcobatos vermiculatus), winterfat (Krascheninnikova lanata) and other species with salt tolerant traits can be utilized to stabilize saline soils and restore ecosystem function in arid and semi-arid regions. 


\section{$\underline{\text { Assisted Plant Community Succession and Reconstructing Ecosystem Function }}$}

\section{$\underline{\text { Assisted Succession }}$}

Incorporating hardy native plants into reclamation seed mixtures increases the value of the ecosystem for pollinators, wildlife and livestock, and potentially improves soil conditions more quickly than non-native plantings alone (Swab et al., 2017). Plant species can be allocated to functional groups to achieve greater integration and logical plant community units, and yet retain a useful link between ecosystem structure and function (i.e., biogeochemical processes and components). Functional groups can be described with respect to such attributes as growth related traits, temperature tolerance, rooting depth, or propagule dispersal ability (Chapin et al., 2011). There are numerous interactions among functional groups with and between different trophic levels - producers (e.g., grasses and forbs) can control one or more consumer levels (e.g., herbivores and carnivores) or, conversely, consumers can control producers. Furthermore, invasive species have the ability to change the physical and biotic environment enough to alter the abundance or possibly displace native species from an ecosystem (Chapin et al., 2011). Because each species in an ecosystem contains genetic traits in somewhat different packages, loss or gain of a species changes the ways in which traits interact to influence ecosystem processes. Therefore, by selecting species appropriately and designing seed mixtures with a suite of traits, reclamation specialists can more effectively shape the successional trajectory of ecosystem development.

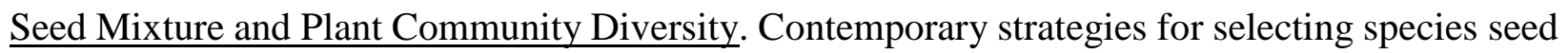
mixtures to be used for reclamation can be best achieved by emphasizing species diversity, functional diversity, assembly rules, and the self-design capacity of ecosystems (Bradshaw, 2004; Whisenant, 2005). Plant traits present in an ecosystem can be represented by distinct species, each of which has a particular set of response and effect traits. For example, species with high capacity for $\mathrm{N}$ absorption, photosynthesis, and growth, respond sensitively to $\mathrm{N}$ supply, produce rapidly decomposing litter, and occupy N-rich sites. Thus, conditions that favor some species will likely reduce the competitive advantage of other functionally similar species (Chapin et al., 2011; Atwater et al., 2015). Rinella and James (2017) demonstrated that combining species with different seed/seedling traits can increase the probability of achieving adequate plant establishment. One central question when designing seed mixtures is which species or functional group should management target during the revegetation process and which suite of functional traits shared by species that are able to successfully resist weed invasion (Drenovsky and James, 2012). 
All functional groups are important; however, some functional groups can address specific limitations of the disturbed site and/or climate. Functional groups that improve hydrologic processes (e.g., infiltration, erosion, or soil structure development), water use efficiency, or microenvironmental conditions are critical in water-limited environments. Much of the stability, resistance, and self-repairing capacity associated with species-rich ecosystems is likely a result of functional group diversity rather than species diversity. Figure 3 shows below ground niche occupation by different functional groups in an arid or semi-arid ecosystem. Cool season shallowrooted species take advantage of early season growth conditions (i.e., moisture and soil temperature) ultimately giving way to warm season and/or deeper-rooted species as the soil profile dries through the summer months. Thus, a functional matrix of traits extends the functional-types approach to consider all the traits present in an ecosystem and is useful guidance in designing seed mixtures for reclamation (Chapin et al., 2011). By selecting appropriate species with specific traits, reclamation specialists can assist the trajectory of ecosystem development.

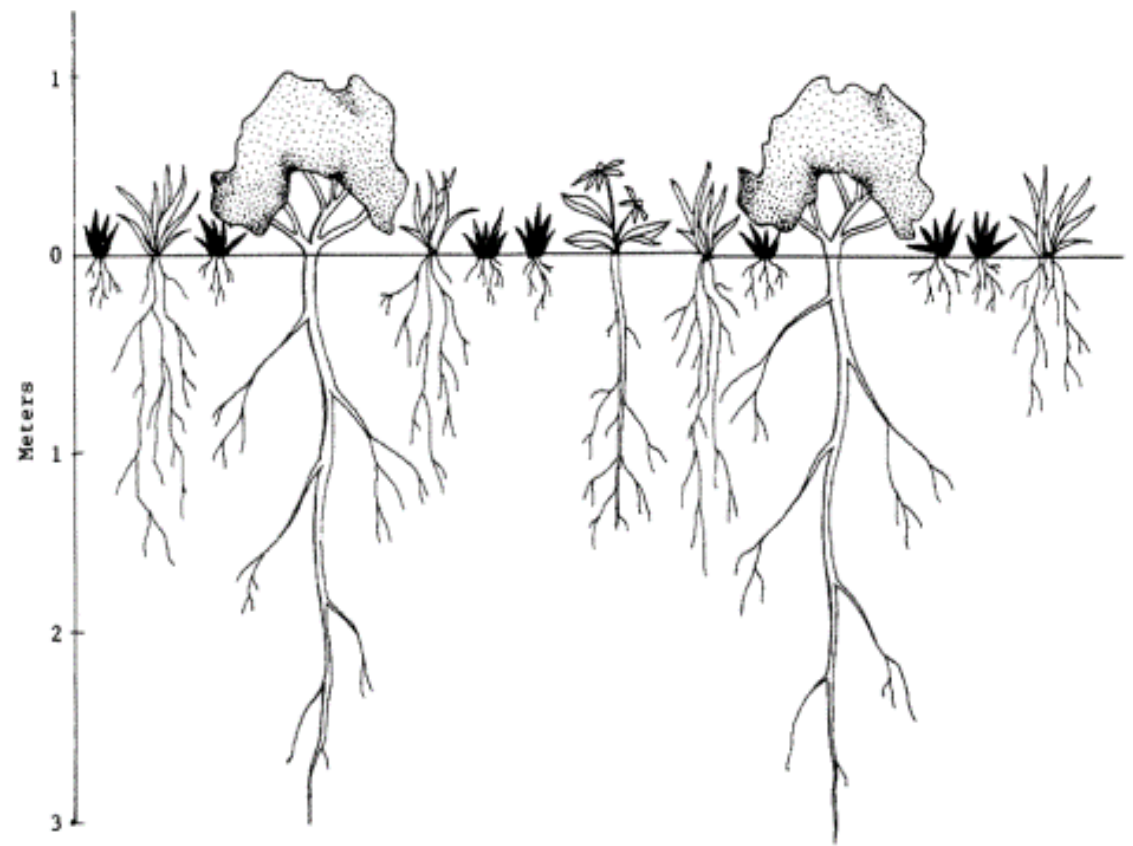

Figure 3. A healthy semi-arid, relatively weed-resistant plant community composed of earlyseason, shallow-rooted species (black), mid-season species with moderately deep roots (white), and late-season, deep-rooted species (grey). Establishing plant communities with diverse belowground functional group niche occupation leads towards fewer open niches susceptible to invasion by exotic invasive species, creates greater interference from neighbors and fewer resources available to exotic annuals. Plant communities are more resistant and resilient to disturbances. Adapted from Sheley et al., (1996) - drawn by Susan Kedzie-Web. 
Propagule Establishment. Ultimately, the capacity of a plant to establish itself and perform (grow) in a reclaimed site depends on its ability to deal with stress caused by abiotic conditions on the site (e.g., unfavorable soil $\mathrm{pH}$, moisture, etc.) or its ability to find safe sites. The primary necessary condition permitting the survival and establishment of desired species and preventing colonization by undesired invasive species in habitats under reclamation is the return of abiotic conditions to a state similar to the state that existed before the impact of mining disturbance (Voigt and Perner, 2004). Where reclamation occurs in harsh environments a number of factors other than biotic interactions can also influence plant establishment and therefore, plant community assembly. These factors include: 1) the ability of propagules to be adequately deployed across the site at sufficient rates to occupy all available safe sites or niches, 2) the level of resources required for plant establishment and growth; and 3) the occurrence of toxic substances. The germination of seeds and subsequent early growth of seedlings are not only essential phases of the life cycle of all higher plants but represent periods of maximum vulnerability to physical changes in the environment (e.g., soil crusting) and marginal potential for homeostatic response (Wagner, 2004; Rinella and James, 2017).

Abiotic and biotic factors limiting reclamation success include drought, soil crusting, extreme temperatures, acidity, salinity, infertile soils, competition from weeds, and predation. Madsen et al., (2015) are exploring seed enhancement technologies having the potential to improve seeding efforts by treating seed prior to sowing with amendments designed to mitigate identified barriers to plant establishment for the site and time of the seed sown. Depending on the species and seed size, seedling emergence can be curtailed as a result of improper seed placement (i.e., too shallow or deep) in the soil. James and Svejcar (2010) found that seedling density was more than 7-fold greater when seeds were sown by hand at the proper depth when compared to seeding with a rangeland drill with minimal control on seed placement.

\section{Reconstructing Ecosystem Function}

Ecosystems have numerous features, not only its flora and fauna but also the functions taking place within it, such as growth, nutrient accumulation, and cycling (Bradshaw, 2004). Reclamation can be thought of as the process of assembling different pieces of materials; however, ecosystem function (i.e., growth, nutrient accumulation, and cycling) is a critical quality of the assembly process. In fact, ecosystem function and the processes it involves are as important to successful assembly of ecosystems as the collecting together of species. Therefore, ecologically- 
based reclamation is a process of reassembly and should take into account growth and other functional processes. Because plant and ecosystem growth cannot occur without sufficient resources, resource availability and acquisition are fundamental to ecosystem function or vigor (Bradshaw, 2004). Three main renewable resources critical to the development of an ecosystem are water, light, and carbon dioxide. Nutrients are non-renewable and are a fourth major resource. Non-renewable resources such as mineral nutrients can impose significant controls on ecosystem development. Consequently, the outcome of reclamation (ecosystem assembly) with respect to performance and species composition depends substantially on nutrient supply and availability.

Ecosystem development can be represented by structure and function as two critical attributes that should be considered and quantified when attempting to reconstruct or assemble ecosystems. Figure 4 is a conceptual model adapted from Bradshaw (2004) illustrating the achievement of a post-mine land use ecosystem where "ecosystem function" (response variable) is a function of "ecosystem structure" (independent variable). Reclaiming surface mined land back to rangeland and/or wildlife habitat requires a balance between ecosystem function and ecosystem structure to successfully reconstruct diverse, effective, and permanent plant communities. Ecologically-based reclamation of ecosystem function requires utilizing principles of surface mine reclamation along with principles of ecology to reconstruct sustainable plant communities designed for their intended post-mine land use. Limiting factors are likely to be manifested in severely disturbed sites; therefore, reclamation depends on the successful recognition and treatment of limiting factors. However, individual plant and ecosystem growth depends on nutrient availability and the activities of plants can alter the amounts and availabilities of nutrients in the soil (Bradshaw, 2004).

Ecologically-based Invasive Plant Management (EBIPM). Active invasive plant management efforts are required to protect and maintain the ecological integrity, function, and productivity of reclaimed sites (Temperton and Zirr, 2004; Shantz et al., 2015). Research indicates that integrating management strategies (i.e., grazing, biological, and chemical controls) has the most potential for long-term success. EBIPM is a systems approach toward developing integrated strategies to repair ecological processes to move plant community change in a favorable direction (James et al., 2012). Consideration of propagule pressure by both desirable plant species and exotic invasive species and their potential to occupy safe sites and become established is required for sustainable reclamation. Once invasive species occupy available safe sites and become established these species potentially out-compete and suppress native species and weeds continue to spread by 
multiple vectors (Davies and Sheley, 2007). In this case, designed disturbance (e.g., herbicide and/or grazing treatments) and re-seeding may be required to open up safe-sites and occupy niches with desirable species. Thus, reclamation specialists should manage species availability, niche occupation, and species performance of both desirable and undesirable species to direct plant community succession toward a desirable trajectory.

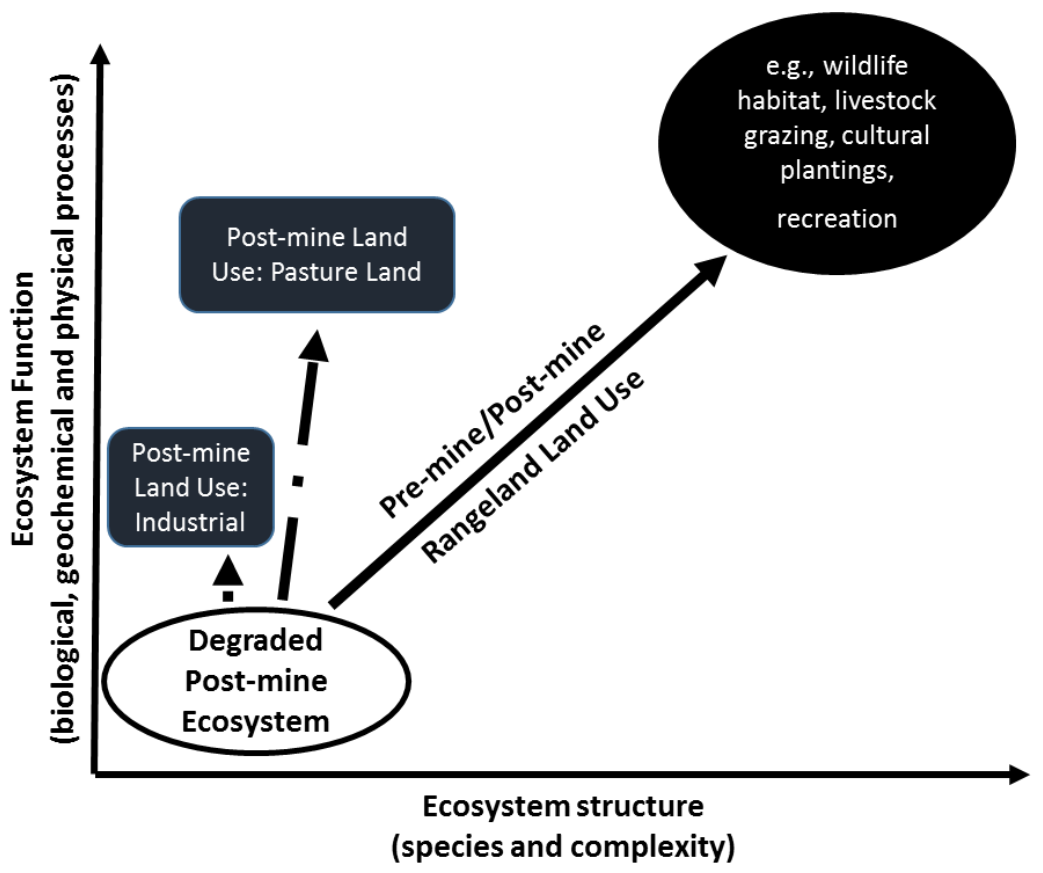

Figure 4. Reclaiming surface mined land requires a balance between ecosystem function and ecosystem structure. Ecologically-based reclamation addresses ecosystem processes and attempts to balance principles of reclamation and ecological restoration to reconstruct diverse, effective, and permanent plant communities designed for their intended post-mine land uses (e.g., rangeland and wildlife habitat). In certain situations, reclaimed lands may be re-purposed for their approved post-mine land use. Adapted from Bradshaw (2004).

Invasive plant management has traditionally focused on controlling invasive plants on alreadyinfested rangelands, with less importance placed on preventing invasion in un-infested sites (Davies and Sheley, 2007). Invasive plant management on reclaimed lands is typically more of a reactive approach once invasive plants have already become established, which is expensive and often requires repeated efforts over the long term and may not be successful despite repeated attempts (Vitousek et al., 1997). Managing invasive plants can increase exponentially as invaders become more entrenched and can become cost prohibitive once populations have fully invaded an ecosystem and have become naturalized (Fig. 5). Eradication refers to the complete removal of a 
weed from an area (both live and reproductive parts) and is different from control efforts. Eradication efforts are thought to be most successful for infestations less than one hectare in size (e.g., introduction phase); in contrast, eradication of infestations larger than 100 hectares is largely unsuccessful, costly, and unsustainable (Rejmanek and Pitcairn, 2002). Once an invasive plant population begins to spread into new sites, containment or holding the line is usually the most costeffective strategy. In other words, eradicate and/or control satellite populations from becoming established. For this reason, resource managers and invasive plant ecologists advocate the need for early detection / rapid response strategies before invasive plants become established and continue to spread (Mack et al., 2000; Vasquez et al., 2010).

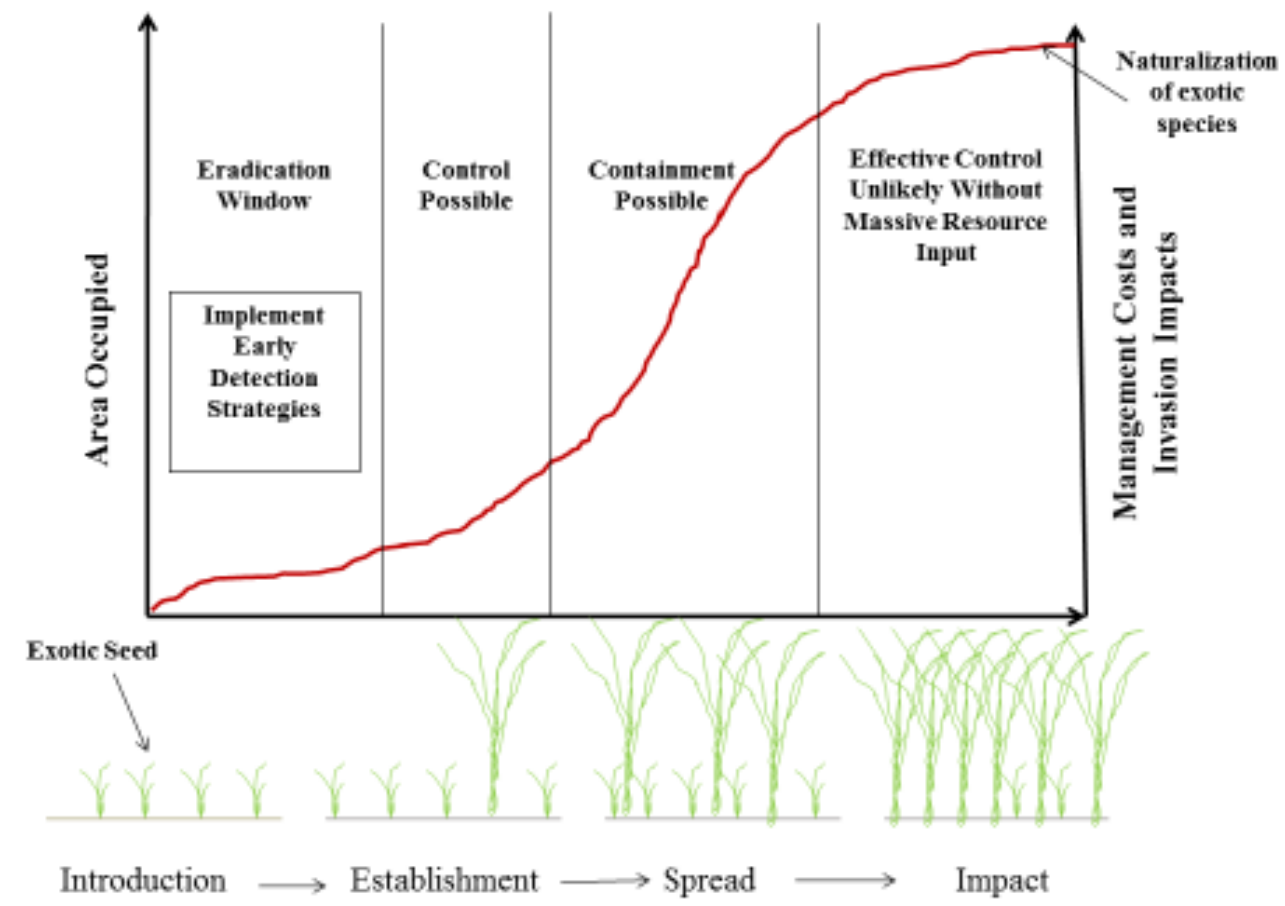

Figure 5. Relationship between biological stages of invasion and associated costs and/or ecological impacts. Appropriate management strategies are shown to illustrate the relevance of the invasion process to management options. As invasive plants become more established, the costs of managing them become significantly greater, to the point of being cost prohibitive or will require massive resource input over the long term. (Adapted from Levine et al., 2004; Vasquez et al., 2010; USGS Early Detection of Invasive Plant Species Handbook, 2014).

Consequently, proactively preventing weed invasion into un-infested sites is the most costeffective management strategy followed by early detection and control of small infestations (Sheley and Petroff, 1999). The initial costs of weed prevention may appear unacceptable; 
however, the cost of weed control once the invasive plant has become fully established can be enormous over the long term (Office of Technology Assessment, 1993; Davies and Sheley, 2007). Following revegetation activities on reclaimed sites, ecological processes can be manipulated to protect or preserve areas at a current desirable state as part of normal husbandry. These measures are preventive in nature and can include actions to prevent weed invasion, including reducing disturbance, limiting weed seed dispersal, and favoring resource capture by desirable species as opposed to invasive plants (Ransom and Whitesides, 2012).

Proactive EBIPM involves systematic planning and implementation of prevention programs. Weed prevention programs are the most cost-effective and efficient method for reducing the costs associated with invasive plants (Davies and Sheley 2007; National Invasive Species Council 2008; Smith and Sheley, 2015). Smith and Sheley (2015) present a flow model with the steps necessary to successfully implement such programs. Their model has three categories from which specific prevention planning occurs: (1) education, (2) early detection and eradication, and (3) interruption of movement. Davies and Sheley (2007) present a framework which conceptually links the invasive plant species characteristics and infestation locations with their modes of dispersal and provides management strategies based on those characteristics. Thus, weed prevention generates benefits that improve ecosystem goods and services; however, it requires widespread support from the public, community action, and long-view investments to mine operators (Goodwin et al., 2012; Bajwa et al., 2018).

\section{$\underline{\text { Management Implications }}$}

Assembling diverse, effective, and sustainable plant communities is a process of putting components together, and the final assessment of success is not whether what has been assembled looks good, but whether it actually does something positive for society or the environment. Designing reconstructed rangelands to be used for grazing and/or wildlife habitat warrants consideration of other trophic levels (e.g., producers, herbivores) (Voigt and Perner, 2004). An important aspect of both natural succession and reclamation is that the processes leading to ecosystem development are not completed suddenly but over a period of time. Because of the relatively short time frame for re-establishing diverse, effective, and permanent plant communities per SMCRA regulations, mine operators are encouraged to develop detailed time tables and/or logistic models to achieve reclamation goals efficiently. 
Monitoring program design should be an integral part of the reclamation planning process. As part of the monitoring protocol, point-in-time qualitative assessments can also be applied to evaluate the status of the reclaimed land relative to its ecological potential (Herrick et al., 2006b). Ecological processes (e.g., infiltration and runoff) can be evaluated as part of normal husbandry using a combination of indicators such as water flow patterns, rills, soil compaction, and the spatial distribution (i.e., basal and canopy gaps of perennial plants) and vigor of the plant community. Continued annual monitoring of soil and vegetative attributes is required for adaptive reclamation often requiring alternative mitigation practices and/or continued husbandry. Monitoring methods should provide a spatially explicit point-in-time snapshot of cover, composition, structure and stability, and generate indicators that relate to hydrologic, erosion and vegetation recovery processes. Thus, monitoring the factors which contribute to reclamation success can be extremely valuable if there is a possibility to adjust management to modify these factors (Herrick et al., 2006b). Where there is a high level of resource distribution among landscape units (i.e., high rates of runoff, wind and/or water erosion) such as found in arid and semi-arid ecosystems, landscape indicators should be identified to be adapted for both reclamation project design and monitoring.

Topsoil materials require careful handling during removal, storage, and application so as to preserve soil structure, nutrients, soil organic carbon (SOC), and nitrogen pools (Shrestha and Lal, 2011). Strategies for developing sustainable reconstructed ecosystems are to manage resource availability and balancing ecosystem structure/function in the planning process for the intended post-mine land use. Adequate nutrients are important for assembly as they allow ecosystem growth and development to occur; however, different species and/or functional groups can have very different adaptations and responses to different nutrients (Atwater et al., 2015). Repeated or continued disturbance to topsoil induces high rates of $\mathrm{N}$ mineralization (Johnson et al., 1995) and native species cannot effectively compete with exotic annual species under high nutrient environments as exotic annuals preempt soil resources (Vasquez et al., 2008; 2010). Topsoil is a potential source of invasive species propagules. Invasive plant seed dispersal strategies or potential vectors of weed invasion suggest topsoil from areas with populations of invasive species should not be direct hauled and placed on the recently graded spoil surface. Understanding the biology and ecology of each invasive plant species with potential to occur in reclaimed areas provides ecologically-based management options for effectively managing the cause of invasion rather than merely addressing the symptoms of weed invasion. 


\section{Acknowledgements}

We thank Dr. Richard Barnhisel and three anonymous reviewers for considerable help with the manuscript. We also thank Marcelo Calle (Hydrologist, Branch Manager - Program Support Division), Mychal Yellowman (Civil Engineer, Indian and Washington Programs Manager), Matthew Hulbert (Civil Engineer, Mine Team Leader) and Jacob Mulinix (Soil Scientist) with the Office of Surface Mine Reclamation Enforcement (OSMRE), Western Region Program Support Branch for their invaluable comments and discussions. Lastly, we like to thank Mychal Yellowman for providing representative photographs.

\section{$\underline{\text { Literature Citations }}$}

Alday, J.G., Y. Pallvicini, R.H. Marrs, and C. Martinez-Ruiz. 2011. Functional groups and dispersal strategies as guides for predicting vegetation dynamics on reclaimed mines. Plant Ecology 212:1759-1775. https://doi.org/10.1007/s11258-011-9947-6

Atwater, D.Z., J.J. James, and E.A. Leger. 2015. Seedling root traits strongly influence field survival and performance of a common bunchgrass. Basic and Applied Ecology 16:128-140. https://doi.org/10.1016/j.baae.2014.12.004

Bajwa, A.A., T. Nguyen, S. Navie, C. O’Donnell, and S. Adkins. 2018. Weed seed spread and its prevention: the role of roadside wash down. Journal of Environmental Management 208:8-14. https://doi.org/10.1016/j.jenvman.2017.12.010

Boyer, S., S. Wratten, M. Pizey, and P. Weber. 2011. Impact of soil stockpiling and mining rehabilitation on earthworm communities. Pedobioligia 54:S99-S102. https://doi.org/10.1016/j.pedobi.2011.09.006

Bradshaw, A. 2000. The use of natural processes in reclamation - Advantages and difficulties. Landscape and Urban Planning 51:89-100. https://doi.org/10.1016/S0169-2046(00)00099-2

Bradshaw, A. D. 2004. The role of nutrients and the importance of function in the assembly of ecosystems. In Temperton, V.M., R.J. Hobbs, T. Nuttle, and S. Halle, 2004. Assembly rules and restoration ecology: bridging the gap between theory and practice. Editors. Island Press, 1718 Connecticut Avenue, NW, Suite 300, Washington, DC 20009. pp. 156-188.

Brady, N.C. and R.R. Weil. 2002. The nature and properties of soils, $13^{\text {th }}$ Ed. Pearson Education, Inc., Upper Saddle River, New Jersey 07458. pp 1-902. ISBN-13 9780132279383 
Brown, R.W., M.C. Amacher, W.F. Mueggler, and J. Kotuby-Amacher. 2003. Reestablishing natural succession on acidic mine spoils at high elevation: long-term ecological restoration. United States Forest Service: Rocky Mountain Research Station - RMRS-RP-41. pp. 1-49. https://doi.org/10.2737/RMRS-RP-41

Bugosh N. 2004. Computerizing the fluvial geomorphic approach to land reclamation. In 2004 National Meeting of the American Society of Mining and Reclamation and the 25th West Virginia Surface Mine Drainage Task Force, April 1 8-24, 2004. Barnhisel RI (Ed). ASMR: Lexington, KY; 240-258. http://dx.doi.org/10.21000/JASMR04010240

Byrne, C.F., J.C. Stormont, and M.C. Stone. 2017. Soil water balance dynamics on reclaimed mine land in the southwestern United States. Journal of Arid Environments 136:28-37. https://doi.org/10.1016/j.jaridenv.2016.10.003

Chapin III, F.S., P.A. Matson, and P.M. Vitousek. 2011. Principles of terrestrial ecosystem ecology, $2^{\text {nd }}$ Ed. Springer Publishing, 233 Spring Street, NY 10013. Pp. 1-447. https://doi.org/10.1007/978-1-4419-9504-9

Costanza, R. 2012. Ecosystem health and ecological engineering. Ecological Engineering 45, 2429. https://doi.org/10.1016/j.ecoleng.2012.03.023

Davis, K.W., M.L. Pokorny, R.L. Sheley, and J.J. James. 2007. Influence of plant functional group removal on inorganic soil nitrogen concentrations in native grasslands. Rangeland Ecology and Management 60:304-310.

https://doi.org/10.2111/1551-5028(2007)60[304:IOPFGR]2.0.CO;2

Davies K.W. and R.L. Sheley. 2007. A conceptual framework for preventing the spatial dispersal of invasive plants. Weed Science 55:178-184. https://doi.org/10.1614/WS-06-161

DePriest, N.C., L.C. Hopkinson, J.D. Quaranta, P.R. Michael, and P.F. Ziemkiewicz. 2015. Geomorphic landform design alternatives for an existing valley fill in central Appalachia, USA: quantifying the key issues. Ecological Engineering 81:19-29. https://doi.org/10.1016/j.ecoleng.2015.04.007

Dollhopf, D.J. 2000. Sampling Strategies for Drastically Disturbed Lands, In Barnhisel, Richard I. et. al. (Eds.) Reclamation of Drastically Disturbed Lands, American Society of Agronomy. pp. 1802. 
Dorr de Quadros, P.D., K. Zhalnina, A.G. Davis-Richardson, J.C. Drew, F.B. Menezes, F.A. de O. Camargo, E.W. Triplett. 2016. Coal mining practices reduce the microbial biomass, richness and diversity of soil. Applied Soil Ecology 98. 195-203. https://doi.org/10.1016/j.apsoil.2015.10.016

Drenovsky, R. and J.J. James. 2010. Designing invasion-resistant plant communities: the role of plant functional traits. Rangelands 32:32-37. https://doi.org/10.2111/RANGELANDS-D-09$\underline{00002.1}$

Franzluebbers, A.J. 2002. Water infiltration and soil structure related to organic matter and its stratification with depth. Soil and Tillage Research 66:197-205. https://doi.org/10.1016/S0167-1987(02)00027-2

Goodwin, K., R. Sheley, J. Jacobs, S. Wood, M. Manoukian, M. Schuldt, E. Miller, and S. Sackman. 2012. Rangelands 34:26-31. https://doi.org/10.2111/1551-501X-34.1.26

Havlin, J.L., J.D. Beaton, S.L. Tisdale, and W.L. Nelson. 2005. Soil fertility and fertilizers: an introduction to nutrient management. $7^{\text {th }}$ Edition. Pearson Education, Inc., Upper Saddle River, NJ 07458. pp. 1-501.

Herrick, J.E., B.T. Bestelmeyer, S. Archer, A. Tugel, and J.R. Brown. 2006a. An integrated framework for science-based arid land management. Journal of Arid Environments 65:319335. https://doi.org/10.1016/j.jaridenv.2005.09.003

Herrick, J.E., G.E. Schuman, and A. Rango. 2006b. Monitoring ecological processes for restoration projects. 2006. Journal for Nature Conservation 14:161-171. https://doi.org/10.1016/j.jnc.2006.05.001

Hillel, D. 1998. Environmental soil physics. Academic Press, 525 B Street, Suite 1900, San Diego, CA. pp. 385-426.

James, J.J. and T.J. Svejcar. 2010. Limitations to positive seedling establishment: the role of seedling technology, water availability, and invasive plant abundance. Rangeland Ecology and Management 63:491-495. https://doi.org/10.2111/REM-D-09-00124.1

James, J.J., R.L. Sheley, and B.S. Smith. 2012. Ecological principles underpinning invasive plant management tools and strategies. https://doi.org/10.2111/RANGELANDS-D-12-00046.1 
Jennings, S.R. and D.J. Dollhopf. 1995. Acid-base account effectiveness for determination of mine waste potential acidity. Journal of Hazardous Materials 41:161-175. https://doi.org/10.1016/0304-3894(95)00003-D

Johnson, D.W., R.F. Walker, and J.T. Ball. 1995. Lessons from lysimeters: soil N release from disturbance compromises-controlled environment study. Ecological Applications 5:395-400. https://doi.org/10.2307/1942030

Jones, D.L., A. Hodge, and Y. Kuzyakov. 2004. Plant and mycorrhizal regulation of rhizodeposition. New Phytologist 163:459-480. https://doi.org/10.1111/j.1469$\underline{8137.2004 .01130 . x}$

Levine, J.M., P.B. Adler, and S.G. Yelenik. 2004. A meta-analysis of biotic resistance to exotic invasions. Ecology Letters 7:975-989. https://doi.org/10.1111/j.1461-0248.2004.00657.x

Li-ping, W., Q. Kui-mei, H. Shi-long, and F. Bo. 2009. Fertilization reclamation of arbuscular mycorrhizal fungi on coal mine complex substrate. Procedia Earth and Planetary Science 1: 1101-1106. https://doi.org/10.1016/i.proeps.2009.09.169

Liu, X, Z. Bai, W. Zhou, Y. Cao, and G. Zhang. 2017. Changes in soil properties in the soil profile after mining and reclamation in an opencast coal mine of the Loess Plateau, China. Ecological Engineering 98, 228-239. https://doi.org/10.1016/j.ecoleng.2016.10.078

Love, M. and K. Bates. 2009. California salmonid stream habitat restoration manual fourth edition. Volume ii, part xii, fish passage design and implementation. California Department of Fish and Game, Wildlife and Fisheries Division. Available at: http://www.dfg.ca.gov/fish/Resources/HabitatManual.asp. Accessed February 8, 2018.

Mack. R.N., D. Simberloff, W.M. Lonsdale, H. Evans, M. Clout, and F.A. Bazzaz. 2000. Biotic invasions: causes, epidemiology, global consequences, and control. Ecological Applications 10:689-710. https://doi.org/10.1890/1051-0761(2000)010[0689:BICEGC]2.0.CO;2

Madsen, M.D., K.W. Davies, C.S. Boyd, J.D. Kerby, and T.J. Svejcar. 2015. Emerging seed enhancement technologies for overcoming barriers to restoration. Restoration Ecology 891: 18

Martin-Duque, J.F., M.A. Sanz, J.M. Bodoque, A. Lucia, and C. Martin-Moreno. 2010. Restoring earth surface processes through landform design. A 13-year monitoring of a geomorphic 
reclamation model for quarries on slopes. Earth Surface Processes and Landforms 35:531-548. https://doi.org/10.1002/esp.1950

Marschner, P. 2012. Marschner's mineral nutrition of higher plants. $3^{\text {rd }}$ Edition. Elsevier Ltd. Pp.1483.

Mitsch, W.J. and S.E. Jorgensen. 2003. Ecological engineering: a field whose time has come. Ecological Engineering 20:367-377. https://doi.org/10.1016/j.ecoleng.2003.05.001

Mossa, J. and L.A. James. 2013. Impacts of mining on geomorphic systems. In: Shroder, J. (Editor in chief), James, L.A., C.P. Harden, and J.J. Clague. (Eds.), Treatise on Geomorphology. Academic Press, San Diego, CA, vol. 13, Geomorphology of Human Disturbances, Climate Change, and Natural Hazards. pp. 74-95.

Mushia, N.M, A. Ramoelo, and K.K. Ayisi. 2016. The impact of the quality of coal mine stockpile soils on sustainable vegetation growth and productivity. Sustainability 8:546 (1-12). Available at: https://www.mdpi.com/2071-1050/8/6/546/pdf. Accessed April 19, 2018.

National Invasive Species Council. 2008. 2008-2012 National Invasive Species Management Plan. Available at http:// www.doi.gov/invasivespecies/upload/2008-2012-National-Invasive Species-Management-Plan.pdf. 35 p. Accessed January 2, 2018.

Natural Resources Conservation Service (NRCS), 2005. Terminology and definitions associated with revegetation. Available at: https://www.nrcs.usda.gov/Internet/FSE_PLANTMATERIALS/publications/wapmctn6333.p df. Accessed on December 20, 2017

Radhakrishnan, R. and K.H. Baek. 2017. Physiological and biochemical perspectives of non-salt tolerant plants during bacterial interaction against soil salinity. Plant Physiology and Biochemistry 116:116-126. https://doi.org/10.1016/j.plaphy.2017.05.009

Rakhsh, F., A. Golchin, A. Beheshti, A. Agha, and Pl. Alamdari. 2017. Affects of exchangeable cations, mineralogy and clay content on the mineralization on plant residue carbon. Geoderma 307:150-158. https://doi.org/10.1016/i.geoderma.2017.07.010

Ransom, C.V. and R.E. Whitesides. 2012. Proactive EBIPM: establishing weed prevention areas. Rangelands 34:35-38. https://doi.org/10.2111/RANGELANDS-D-12-00055.1 
Rejmanek, M. and M.J. Pitcairn. 2002. When is eradication of exotic pest plants a realistic goal? Pages 249-253 in C. R. Veitch and M. N. Clout, editors. Turning the Tide: the Eradication of Invasive Species. IUCN SSC Invasive Species Specialist Group. IUCN, Gland, Switzerland and Cambridge, UK.

Reynolds, B. and K.J. Reddy. 2012. Infiltration rates in reclaimed surface coal mines. Journal of Water Air Soil Pollution 223:5941-5958. https://doi.org/10.1007/s11270-012-1330-2

Rinella, M.J. and J.J. James. 2017. A modelling framework for improving plant establishment during ecological restoration. Ecological Modelling 361:177-183. https://doi.org/10.1016/j.ecolmodel.2017.08.005

Ryel, R.J., M.M. Caldwell, A.J. Leffler, and C.K. Yoder. 2003. Rapid soil moisture recharge to depth by roots in a stand of Artemisia tridentata. Ecology 84: 757-764. https://doi.org/10.1890/0012-9658(2003)084[0757:RSMRTD]2.0.CO;2

Sanger, H. and G. Jetschke. 2004. Are assembly rules apparent in the regeneration of a former uranium mining site? In Temperton, V.M., R.J. Hobbs, T, Nuttle, T., and S. Halle. 2004. Assembly rules and restoration ecology: bridging the gap between theory and practice. Editors. Island Press, 1718 Connecticut Avenue, NW, Suite 300, Washington, DC 20009. Pp. 305-324.

Schantz, M., R.L. Sheley, and J. James. 2015. Role of propagule pressure and priority effects on seedlings during invasion and restoration of shrub-steppe. Biological Invasions. 17:73-85. https://doi.org/10.1007/s10530-014-0705-2

Schroeder, S.A. and K.C. Vining. 1993. Relation of compaction and soil physical parameters to productivity or reclaimed soils. Available at: https://www.osmre.gov/resources/library/pub/relatcmp.pdf. Accessed December 29, 2017.

Sheley, R.L., T.J. Svejcar, and B.D. Maxwell. 1996. A theoretical framework for developing successional weed management strategies on rangeland. Weed Technology 7:766-773. https://doi.org/10.1017/S0890037X00040793

Sheley, R.L. and J.K. Petroff (Ed.). 1999. Biology and management of noxious rangeland weeds. Oregon State University Press, Corvallis OR, 97331. pp. 1-407. 
Shrestha, R.K. and R. Lal. 2011. Changes in physical and chemical properties of soil after surface mining and reclamation. Geoderma 161:168-176. https://doi.org/10.1016/j.geoderma.2010.12.015

Skousen, J., A. Rose, G. Geidel, J. Foreman, R. Evans, W. Hellier, et al., 1998. Handbook of technologies for avoidance and remediation of acid mine drainage. Available at: https://www.osmre.gov/resources/library/ghm/hbtechavoid.pdf. Accessed on November 29, 2017.

Smith, B.S. and R.L. Sheley. 2015. Implementing strategic weed prevention programs to protect rangeland ecosystems. Invasive Plant Science and Management 8:233-242. https://doi.org/10.1614/IPSM-D-13-00075.1

Spargo, A. and D. Doley. 2016. Selective coal mine overburden treatment with topsoil and compost to optimize pasture or native vegetation establishment. Journal of Environmental Management 182, 342-350. https://doi.org/10.1016/j.jenvman.2016.07.095

Sparks, D.L. 2003. Environmental soil chemistry. Second Edition. Academic Press, 525 B Street, Suite 1900, San Diego, CA 92101. pp. 285-300.

Stevenson, F.J. and M.A. Cole. 1999. Cycles of soil: carbon, nitrogen, phosphorus, sulfur, micronutrients. John Wiley and Sons, Inc., 111 River Street, Hoboken, NJ 07030

Surface Mining Control and Reclamation Act (SMCRA). 1977. Available at: https://www.osmre.gov//rg/docs/SMCRA.pdf. Accessed on December 20, 2017.

Swab, R.M., N. Lorenz, S. Byrd, and R. Dick. 2017. Native vegetation in reclamation: improving habitat and ecosystem function through using prairie species in mine land reclamation. Ecological Engineering 108 (Part B):525-536. https://doi.org/10.1016/i.ecoleng.2017.05.012

Temperton, V.M. and K. Zirr. 2004. Order of arrival and availability of safe sites: an example of their importance for plant community assembly in stressed ecosystems. In Temperton, V.M., R.J. Hobbs, T. Nuttle, and S. Halle, 2004. Assembly rules and restoration ecology: bridging the gap between theory and practice. Editors. Island Press, 1718 Connecticut Avenue, NW, Suite 300, Washington, DC 20009. Pp. 1-420.

Thavamani, P., R.A. Samkumar, V. Satheesh, S.R. Subashchandrabose, K. Ramadass, R. Naidu, K. Venkateswarlu, and M. Megharaj. 2017. Microbes from mined sites: harnessing their 
potential for reclamation of derelict mine sites. Environmental Pollution 230:495-505. https://doi.org/10.1016/j.envpol.2017.06.056

USGS Early Detection of Invasive Plant Species Handbook. 2014. Available at: http://www.pwrc.usgs.gov/brd/invasiveHandbook.cfm.

Vasquez E., E. Glenn, J. Brown, G. Guntenspergen, and S. Nelson. 2006. Salt tolerance, osmotic adjustment of Spartina alterniflora and the invasive M haplotype of Phragmites australis along a salinity gradient. Journal of American Botany 93:1784-1790. https://doi.org/10.3732/ajb.93.12.1784

Vasquez, E., R. Sheley, and T. Svejcar. 2008. Creating invasion resistant soils via nitrogen management. Invasive Plant Science and Management 1:304-314. https://doi.org/10.1614/IPSM-07-059.1

Vasquez, E.A., J.J. James, T.A. Monaco, D. C. Cummings. 2010. Invasive plants on rangelands: a global threat. Rangelands 32:3-5. https://doi.org/10.2111/RANGELANDS-D-09-00006.1

Vitousek, P.M., C.M. D’Antonio, L. Loope, M. Rejmanek, and R. Westbrooks. 1997. Introduced species: a significant component of human-caused global change. New Zealand Journal of Ecology 21:1-16.

Voigt, W. and J. Perner. 2004. Functional group interaction patterns across trophic levels in a regenerating and seminatural grassland. In Temperton, V.M., R.J., Hobbs, T. Nuttle, S. Halle, 2004. Assembly rules and restoration ecology: bridging the gap between theory and practice. Editors. Island Press, 1718 Connecticut Avenue, NW, Suite 300, Washington, DC 20009. pp. 156-188.

Wagner, M. 2004. The roles of seed dispersal ability and seedling salt tolerance in community assembly of a severely degraded site In Temperton, V.M., R.J., Hobbs, T. Nuttle, S. Halle, 2004. Assembly rules and restoration ecology: bridging the gap between theory and practice. Editors. Island Press, 1718 Connecticut Avenue, NW, Suite 300, Washington, DC 20009. pp. 266-284.

Waterhouse, B.R., K.L. Adair, S. Boyer, and S.D. Wratten. 2014. Advanced mine restoration protocols facilitate early recovery of soil microbial biomass, activity and functional diversity. Basic Applied Ecology 15:599-606. https://doi.org/10.1016/j.baae.2014.09.001 
Whisenant, S.G. 2005. Repairing damaged wildlands: a process-oriented, landscape-scale approach. Cambridge University Press. Cambridge CB2 2RU, UK. Pp. 1-257.

Yan, N., P. Marschner, W. Cao, C. Zuo, and W. Qin. 2015. Influence of salinity and water content on soil microorganisms. International Soil and Water Conservation Research 3: 316-323. https://doi.org/10.1016/j.iswcr.2015.11.003 